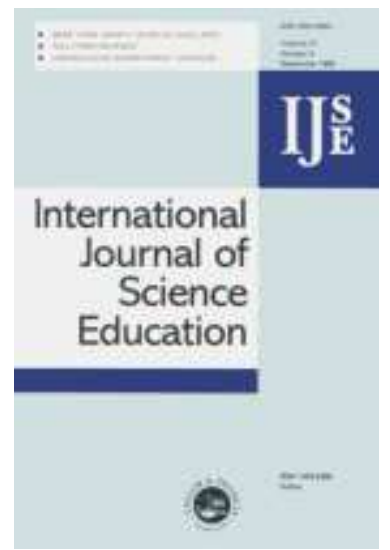

\title{
Classroom implementation of context-based chemistry education by teachers: the relation between experiences of teachers and the design of materials.
}

\begin{tabular}{|r|l|}
\hline Journal: & International Journal of Science Education \\
\hline Manuscript ID: & TSED-2010-0029.R1 \\
\hline Manuscript Type: & Research Paper \\
\hline Keywords: & $\begin{array}{l}\text { chemistry education, classroom, curriculum, qualitative research, } \\
\text { teacher development }\end{array}$ \\
\hline Keywords (user): & implementation \\
\hline
\end{tabular}

\section{S) ScholaroNE \\ Manuscript Central}




\section{Introduction}

Worldwide, a tendency is visible in which upper secondary science curricula are innovated in the direction of context-based education (Bennett, Lubben \& Hogarth 2007; Gilbert, 2006; Nentwig \& Waddington, 2005). The German 'Chemie im Kontext' project is an example of such an innovation (Parchmann et al., 2006, Demuth, Gräsel, Parchmann \& Ralle, 2008). In the last decade innovative contextbased teaching materials have been designed, evaluated and subsequent professionalization courses have been organized. We focus on researching how these teaching materials are used in classroom practice, aiming at the identification of factors influencing adequate implementation of a new context-based programme. Therefore, we performed a series of case studies in the Netherlands (Authors, submitted) and Germany. This paper describes case studies on the classroom implementation of 'Chemie im Kontext' teaching materials by four teachers with different degrees of experiences with these materials. The general question guiding our research is: What are characteristics of the interaction between innovative context-based materials and teachers that hinder or facilitate classroom implementation as intended by the designers?

\section{Theoretical perspective}

To identify factors influencing implementation of context-based education, a framework was developed and tested for analyzing the use of innovative contextbased teaching materials by teachers in classroom practice (Authors, in press; see also Figure 1). Application of this framework to the implementation of a context-based teaching unit by a number of Dutch chemistry teachers provided valid and reliable results. To generalize these results the framework was used in case studies on the 
implementation of 'Chemie im Kontext' (CHiK) teaching materials by German chemistry teachers. The innovation of the chemistry curriculum in the Netherlands is highly comparable to the introduction of 'Chemie im Kontext' in Germany; the framework can also be applied.

The innovation of the curricula in both countries are characterized by the same principles (Driessen \& Meinema, 2003; Demuth et al., 2008). First of all, both are based on contexts. Contexts are used as the starting point and anchor for learning new concepts, thereby giving the curriculum more coherence and helping students in experiencing chemistry as meaningful and relevant (Gilbert, 2006; Pilot \& Bulte, 2006; Nentwig, Parchmann, Demuth, Gräsel \& Ralle, 2005). The framework is developed in such a way that it enables the finding of congruencies and discrepancies in the use of the context in the teaching materials as well as in teaching practice.

Secondly, both innovations aim at the development of a limited set of basic chemical concepts. In this, the curricula focus on a shift from being mainly oriented to the theory-driven 'Fundamental Chemistry' (FC) emphasis towards an increased importance for 'Knowledge Development in Chemistry' (KDC) and 'Chemistry, Technology and Society' (CTS) emphases. Roberts' concept of curriculum emphases (Roberts, 1982, 1988; Van Driel, Bulte \& Verloop, 2005) is a main feature of the framework as a means of identifying the aims in the design of the teaching materials and the way these aims are perceived and implemented by teachers.

Thirdly, the teaching-learning strategies in both curricula aim at providing knowledge acquisition on a 'need-to-know' basis which emerges from the context, and at giving students ownership over what they do (Bulte, Westbroek, De Jong \& Pilot, 2006; Nentwig et al., 2005). This leads to an increased amount of student selfdirected learning activities, resulting in less teacher-controlled teaching activities. 
The analytical framework was developed in order to analyse the way in which the goals of the designers are connected to the teaching-learning strategy and concrete teaching activities. For this, three 'levels of thinking and acting' are employed (Van Hiele, 1986; Korthagen \& Kessels, 1999), distinguishing concrete teaching activities on ground level from teaching-learning strategy on descriptive level and aims and vision on theoretical level. In the framework these are represented as the columns (see Figure 1).

The analysis will indicate whether the teaching materials (the intended curriculum representing the intentions of the designers) are coherently designed, a prerequisite factor for adequate implementation. Also, the framework is used to analyse the perceptions of the teachers concerning the intended aims, strategy and activities (perceived curriculum representing the teachers interpretation of the materials), and the implementation in classroom practice (operational curriculum representing how the materials are used). The framework facilitates study of the implementation from the intended curriculum to the operational curriculum via the perceived curriculum (Goodlad, 1979; McKenney, Nieveen \& Van den Akker, 2006). Following the concept of curriculum representations, implementation is considered adequate if all representations are in alignment with each other, i.e. if intended, perceived and operational curriculum are coherent. In the framework these are represented as the rows (see Figure 1).

Overall, the framework for analysis consists of a nine cell matrix. Adequate classroom implementation is threatened by each discrepancy between two distinct cells. If all cells are coherent with each other, implementation can be considered as ideal. Incoherencies between cells indicate factors hindering adequate 
implementation. This will enable the identification of factors influencing adequate implementation of context-based teaching materials.

\section{[Insert Figure 1 about here]}

Based on the literature and the results of the Dutch case studies (Authors, submitted) two hypotheses guided the study described in this paper.

The first hypothesis states that if concrete and direct instructions are not adequately supporting teachers in the implementation of concrete teaching activities, implementation of the teaching materials as intended by the designers will not take place. This will also be the case if the teacher does not have a repertoire of teaching activities available that is adequate for context-based teaching, even when the concrete and direct instructions are expected to be sufficient. Without an adequate implementation of concrete teaching activities, the intended teaching-learning strategy will not be followed and the intended emphasis will not be realized. Gilbert (2006) assigned the existence of a focal event as a crucial aspect of context-based approaches. Previous case studies in our research project indicated that a context which provides a focal event to guide the activities of the students, as well as of the teachers, is effective in providing the needed concrete and direct instructions.

The second hypothesis concerns value congruence (Johnston, 1992; Harland \& Kinder, 1997): if value incongruence between the teachers' perceptions of the materials and the designers' intentions with the materials exists, then implementation as intended will be hindered. Value congruence is defined as coherence between teachers' and designers' values on aspects regarding the role of the teacher, the way students learn, the relative importance of chemistry content and how this should be 
taught (Cronin-Jones, 1991). Teachers' values are built from personal and professional experience, and have their effects on decision making, planning and executing teaching activities. Designers' values are represented in the teaching materials indicating the content aimed at and the strategy intended to teach this.

Although previous case studies indicate that value congruence is less important then adequate facilitation in terms of concrete teaching instructions (hypothesis 1), it is expected to play a crucial role in the cases of German chemistry teachers implementing CHiK-materials. These materials are designed from the perspective that each teacher can plan their lessons according to their own perceptions and according to the educational standards in the different states of Germany (Nentwig et al., 2005; Demuth et al., 2008). It is known that teachers tend to adapt a new curriculum during implementation according to their own context and beliefs (Coenders, Terlouw \& Dijkstra, 2008). Our expectation was that a higher level of value congruence is demanded in such a situation to have the vision of the designers implemented in classroom practice.

It is expected that the amount of previous experiences with context-based teaching materials is a relevant factor influencing the impact of both hypotheses. During a first encounter with innovative materials a teacher's initial concern will be on what to do in the classroom (Van den Akker, 1994; Deketelaere \& Kelchtermans, 1996). It will require more then one cycle of applying the materials before teachers understand how to use them and develop new routines adequate for implementing their perceptions of the materials (Borko, 2004; Davis \& Krajcik, 2005).

It is expected that teachers' values will play a more crucial role when teachers grow in experiences with the materials, because they will be more confident in adapting the materials to their own perceptions. Hence, value congruence (hypothesis 
2) will have a crucial effect on the implementation process if teachers have previous experiences with context-based education. Besides, these, teachers will depend less on the ground-level instructions in comparison to teachers unfamiliar with using contextbased teaching materials, and when they will have build up a repertoire of teaching activities adequate for context-based education on which they can rely. Hence, concrete instructions to teachers and the teachers' repertoire of teaching activities (hypothesis 1) will have a less important effect on the implementation process in the cases of teachers with previous experiences of context-based education.

Using the analytical framework and the hypotheses for the case studies in the implementation of the 'Chemie im Kontext' teaching materials by German chemistry teachers, our research questions are:

1. To what extent do the 'Chemie im Kontext' teaching materials have a coherent design?

2. To what extent are these materials implemented adequately by German teachers with different degrees of experiences with context-based education?

3. Which factors in teachers and material hinder or facilitate the implementation of such material as intended? In particular: do inadequate instructions and value incongruence hinder implementation of the teaching materials as intended?

\section{Method}

To answer these questions a short description is given of the procedure for data collection and analysis. A more extensive description is given by Authors (in press). Next, the general characteristics of the selected teaching materials and the participating teachers are described. 


\section{Procedure for data collection and data analysis}

The procedure for data collection and subsequent analysis is structured according to the framework (Authors, in press). It comprises three steps of which each step focuses on one row of the framework (see Figure 2). Data collection in each step employs multiple data sources, allowing triangulation. The analysis of each step aims at categorization of the characteristics in each cell and the evaluation of the relations between the cells in the particular row in order to assess their coherency.

Step 1 (upper row in Figure 2) comprises document analysis (students' books, teachers' guides and other accompanying materials) and an open interview with the main designer about the philosophies and design principles. The analysis focuses on the intentions in the design of the materials as presented to the teachers concerning rationale, strategy and teaching activities. The coding took place according to emphasis (Van Driel, Bulte \& Verloop, 2005) and instructional functions as described by Vermunt \& Verloop (1999) and Shuell (1996). This step also involves the identification of critical episodes: comparing the data on the three cells will indicate if there are incoherencies in the design which might pose barriers to adequate implementation. These are clearly defined instructional fragments, critical for the context-based design according to $\mathrm{CHiK}$, as inferred from the framework for analysis. These critical episodes are therefore used as foci to structure the data analysis in steps 2 and 3.

Step 2 involves data collection by video and audio recordings and observations of classroom activities and teacher interviews after each lesson (bottom row in Figure 2). The interview starts with inviting them to explain their teaching, asking them if they appreciated that lesson and to describe their teaching and their aims with the lessons. The analysis focuses on how emphasis, instructional functions and teaching activities 
are used in classroom practice, using the same coding as in step 1. The critical episodes are given particular attention by comparing these data with the results of the first step to check the adequacy of implementation.

Step 3 involves data from a final evaluative interview and a validated questionnaire (middle row in Figure 2). This step is to reveal perceptions of teachers about the materials and its use in practice. The evaluative interview taken after the completion of the unit provides an opportunity for more critical questions about the implementation itself and the teacher's opinions about the materials. The questionnaire contains propositions on emphases to measure teachers' conceptions on teaching and learning chemistry. It was validated and translated into German by Markic, Eilks, Van Driel and Ralle (2009).

Finally, in a fourth step, a birds-eye perspective is taken over all nine cells to assess the correspondence between the cells. This will indicate whether implementation was adequate (correspondence between intended and operational curriculum) and which factors were hindering or facilitating this.

[Insert Figure 2 about here]

\section{Selection of teaching materials}

A fundamental assumption behind the analytical framework is that for adequate classroom implementation coherence is needed between the three cells of the intended curriculum, i.e., a coherent design of the materials on all three levels of thinking and acting is necessary as a first criterion for successful implementation. To check this, the 'Chemie im Kontext' student handbook (Demuth, Parchmann \& Ralle, 2006) was inspected. It contains thirteen context-based chapters, each introducing a new context, 
and based on a selection of previously developed free-standing teaching-units, which were written over a number of years. In these context-chapters references are made to chapters in the second part of the book, describing in a traditional way the subject matter. Furthermore, a CD-ROM is included, containing assignments, experiments and background knowledge, which can be used as a data-source for planning the lessons. It is expected that these teaching materials are coherently designed according to the principles of 'Chemie im Kontext' (Demuth et al., 2008) and as such communicated to the teachers. Coherency in design was checked during step 1 of the procedure for analysis. The way teachers used these materials was the focus of step 2 and 3.

\section{Participants}

Data for analysis of the intended curriculum includes an interview with the designers of CHiK-materials. One of the co-authors of the CHiK-handbook was selected, a professor in the pedagogy of chemistry who was actively involved in the development of the CHiK-rationale and the design of the actual materials. During the period of the observation, the first author of this paper was welcomed as a foreign guest to study the implementation of the CHiK-teaching materials as a researcher and independent outsider. The other authors had no relation with the CHiK designers or teachers. The purpose was to study the way teachers deal with the materials and to view the implementation process critically. For this, the analytical framework above described was used, originally developed to study the implementation of context-based teaching materials in the Netherlands.

Teachers in North Rhine-Westphalia, Germany have been asked to participate in our research project. They had to comply with the following criteria: they must have a 
teaching degree in chemistry, teach in 11th grade (students aged 16 years) and teach at different schools. Furthermore, they were selected randomly taking into account that they differ in the amount of actual experiences with the CHiK-materials. They were asked to select a chapter from the handbook that fits with their regular teaching programme and use this in the lessons of at least one group of students. Four teachers took part.

Teacher I (female, 10-15 years experience, teaching degree in chemistry \& biology) is involved in the CHiK-project as a co-developer of units. She is currently also working as a teacher trainer at a university. She uses for all her chemistry classes the CHiK-teaching materials. The data show her teaching a chapter of the CHiKhandbook in two parallel classes (respectively of 18 and 20 students).

Teacher II (female, 5-10 years experience, teaching degree in chemistry \& biology) has been using CHiK-teaching materials for one year. The data show her teaching a chapter of the handbook in two parallel classes (respectively 23 and 25 students). She attended training in the use of two different units, but was not trained in the use of this specific chapter.

Teacher III (male, 5 years experience, teaching degree in chemistry \& sports) applied one chapter in one of his classes (18 students). He has no experiences in classroom with $\mathrm{CHiK}$ but during his in-service teacher training in chemistry he was familiarized with the basic features.

Teacher IV (female, $>15$ years experience, teaching degree in chemistry \& mathematics) was using CHiK-teaching materials for the first time in her career, without any training or instruction others then the teachers' guide. She applied the materials in one of her classes (20 students). 


\section{Results}

\section{Intended curriculum}

The analysis of the teaching materials focuses first on the three cells of the intended curriculum (Figure 2), before the relations between these cells are described in order to answer the first research question: To what extent do the 'Chemie im Kontext' materials have a coherent design? The designers' intentions with the materials are described from the perspective of the teachers who have to work with those materials. in order to view if communication to them is coherent. Analysis is done to reveal (in)coherence: what is necessary to be implemented in practice according to the intentions of the designers (coherence between intended and operational curriculum). Are the intentions of the designers' on emphasis, teaching-learning strategy and teaching activities communicated coherently to the teachers (coherence between the cells of the intended curriculum). Analysis of the intended curriculum focused on the identification of critical episodes which appeared to pose barriers for implementation.

All context-chapters of the handbook follow the same design, based on a general design model (see Figure 3). Within this model, descriptions for teachers on the three different levels of thinking and acting can be recognized. It describes the educational goals, the teaching-learning strategy and provides the structure for activities in the classroom. This design model is extensively described in the teachers' guide (Demuth, Parchmann \& Ralle, 2007). As one of the main designers states in the interview: 'Our teachers do know the four phases of CHiK, of course!' The design model is related to the three key features of $\mathrm{CHiK}$, namely context-based learning, the development of basic concepts and student-oriented learning activities (Parchman et al., 2006). 
[Insert Figure 3 about here]

\section{Cell 1: Emphasis}

The central spine of 'Chemie im Kontext' is its cyclic four-phase design model (Figure 3), which the designers developed in 2000. Since the German educational standards were published in 2004 this design is used to foster students' development in four areas of competencies which are outlined there. The cycle starts again in each chapter with the introduction of a new context. In each phase one or two of the competencies should receive special attention. Each competency targets an emphasis. The competency 'subject matter knowledge' is oriented at the FC-emphasis, 'scientific methodologies' and 'debate/reasoning' at the KDC-emphasis and 'communication' at the CTS-emphasis.

However, the designers' intention with the CHiK-materials is that in classroom practice the four competencies become interwoven. This should connect the three emphases to one so-called 'Nature of Science' emphasis (Abd-El-Khalick \& Lederman, 2000; Lederman 2007). This refers to students learning, showing them what it means to do chemistry instead of learning about it as a static body of knowledge. As the designer states in the interview: 'You can only communicate in a chemistry lesson if you understand what you are going to communicate. All of the other three competencies are always connected to subject knowledge. Chemie im Kontext has the aim that these four areas of competencies are very strongly integrated into the whole process of learning and teaching.'

Analysis of each chapter in the handbook indicates that the main emphasis orientation can differ per chapter. Whereas in one chapter the main issue of a context 


\section{Cell 2: Teaching-learning strategy; context employed to elicit students' questions}

The teaching-learning strategy, in which the context has a central role, is closely linked to the design model (Figure 3). Specific instructional functions are attended to in each of the four phases. The designers intend that within the phase of contact (1) the context is introduced to the students in such a way that they can relate it to their daily life, bringing in their own experiences and evoke questions based on their curiosity. 'Motivation' is a central function in this phase. As the designer mentions: 'The context gives to them meaning of what they are going to do in school. Meaning will grow when you combine new information with what you know.' It is intended that the first phase is closely linked to the phase of curiosity and planning (2) which has the main function of 'orientation'. Based on their prior knowledge, the students should 'now develop their questions and combine these with ideas for dealing with them, by carrying out experiments to study the issue/problem which has been evoked by the context.' Hence, the formulation of specific questions should serve the function 'orientation', and is intended to lead to the focal event (Gilbert, 2006) for the following lessons, in which students and teachers employ activities for answering 
these questions. The phase of elaboration (3) should be planned with these questions and ideas as a guideline. This phase is meant for the acquisition and application of new knowledge in order to find answers to the questions in a scientific way and to communicate about this with each other. The phase of deepening and connecting (4) should have a central role for 'reflection' on what the students have done and learned. According to the designer, it is important that within the context answers are given to the questions formulated in phase 2. At the same time, it is crucial that a coherent and applicable knowledge base is constructed based on the chemistry content dealt with in the context.

The analysis indicated that the key element of the teaching-learning strategy in the design model is that the context elicits students' questions which should be employed within the focal event for exploring and studying the content. If this is implemented as such in classroom practice, it is expected that the focal event will provide the motive to communicate, argue, study and develop knowledge: the three emphases will be addressed. Therefore, it can be concluded that coherence exists between the intended aims and the teaching-learning strategy.

\section{Cell 3: Student-controlled learning activities}

The CHiK-handbook is structured in such a way that the teacher can plan their own lessons, using the materials on the CD-ROM as a data source. A key principle in the design of 'Chemie im Kontext' is the purposeful application of a range of teaching methodologies, fitted to the aims of each phase and to the expectations of the students and also suitable for student-controlled cooperative activities (Demuth et al., 2008). This means that student-controlled learning activities are intended to be the core of the lessons. This implies that large differences in classroom practice can be expected, even between two classes who are taught by the same teacher. This is founded in the 
idea that learning is situated, a guiding principle underlying CHiK (Mandl \& Kopp, 2005), in which the learner plays a crucial role. As one of the main designers states in the interview: 'The idea behind the design model and the four phases is that the students should work very independently and self-responsibly. The teachers are told that the materials should allow the students to do so. When questions arise, do not give the answers immediately. Leave the answers away. That is one main aspect.' It is expected from the teacher to provide a setting in which the student activities are aimed at actually doing chemistry following their own questions and curiosities. Learning activities should be sequenced in such a way that students themselves discover the need to expand their knowledge in the desired direction (need-to-know principle).

The analysis indicated that, while what goes on in classroom practice is highly influenced by the students, concrete ground-level instructions in the materials to the teachers are limited. The teachers' guide contains general suggestions for the organization of different teaching methodologies (e.g., group work, brainstorming). It is intended that the questions evoked by context direct further activities, i.e., the questions have to serve as the focal event. Hence, we conclude that the intended student-controlled learning activities are coherent with the intended teaching-learning strategy in which the focal event has a crucial role.

\section{Conclusions on the intended curriculum}

With respect to the intended curriculum we therefore can conclude that the design of the materials is coherent (but complex) and that it is communicated as such to the teachers. Analysis of the materials provided two episodes expected to be critical for implementation as intended. 
Critical episode 1: inciting students' questions to serve as focal event.

The first critical episode is in the phase of curiosity and planning (2). In relation to the problem posed by the context, students' questions should be identified and developed in such a way that these can be studied and related to hypotheses based on prior knowledge. According to the designers, it will be impossible to address all questions equally, although it is important that all should be taken seriously. If these questions are not made explicit, they can not serve as the focal event to plan students' activities in further lessons and implementation will not be as intended. Students experimenting and answering their own questions and hypothesis should finally result in the construction of the desired knowledge and competencies. This episode is a key element in the teaching-learning strategy and crucial for the student-controlled learning activities which are intended to follow. It should result in student-controlled planning for the rest of the chapter.

It is concluded that implementation as intended of this episode will be difficult for teachers. It is expected by the designers that 'the students will hopefully have questions regarding the context'. For this 'the contact phase has to be created in such a way that the question will be raised by the students themselves. That is the idea, but it does not always work in that way.' On the other hand, the designers also expect: 'What the teacher has to do is to take these questions in the right direction for the phase of curiosity so that they will be able to follow up their aims.' This is new for most teachers and might be difficult. 'The problem is often that the teacher is a little bit afraid that the context will raise questions from the students that will lead in a wrong direction. Not in the direction the teacher has in mind, and the students will go in the wrong direction so that is very difficult to bring them back to the core of the lesson.' 


\section{Critical episode 2: elaboration/student-controlled activities}

The second critical episode is chosen in the phase of elaboration (3); a setting should be provided in which students work cooperatively and productively on a deeper understanding of the problem, instigated by the context. The focal event, incited by their own questions and hypotheses (episode 1), should work as a point of orientation for their activities. It is intended by the designers that small student groups will work on specific questions regarding the problem posed by the context and communicate their results afterwards. 'If they are not able to pick up all the issues and results of the other groups who are at the same time working on other topics. (...) and bring them together to construct a concept, then what they have done is not very useful, because they will only have a small aspect of the whole topic, and that is not enough.' The aim for this critical episode is that students construct together knowledge and communicate this with each other. The designer said: 'the underlying expectations are of course that the students will also get competencies in communication and debate. That is very important.'

It is concluded that this will be difficult to accomplish in classroom practice. Especially in this phase students control what goes on in the classroom, implying for the teachers a completely new way of planning lessons. According to the designer, the role of the teacher is 'to keep the overview, but our experience is that if the students get used to this kind of work then they become more and more self-responsible and that the teacher is not so nervous to check what each group is doing, they can rely on what the students are doing.' Although these student-controlled activities are recognized as a crucial aspect of $\mathrm{CHiK}$, the materials are not explicit and clear about it. The teaching materials contain group-work assignments with suggestions for their organization. Concrete instructions about how the lessons should go are limited, 
which is a consequence of the intentions that the materials should allow a variety of teaching methods. This episode is identified as critical because it is crucial in the learning process, which should finally result in concept-development. It is up to the teachers how they will organize their lessons, although it is intended that studentcontrolled activities will take place, something the teachers are not used to. They will not be able to build on their conventional 'teacher-centred' routines. Therefore, it is far from evident that teachers will be able to implement this episode as intended by the designers.

\section{Operational curriculum}

The findings about the four cases (teachers) are described separately for each critical episode. The findings show the way each teacher implemented the two critical episodes in their classroom. This provides an answer to the second research question: To what extent are these materials implemented adequately by German teachers with different degrees of experiences with context-based education?

\section{Implementation of critical episode 1}

Teacher I used an open assignment in which the students were able to explore their own ideas. They were asked which of three acidic cleaners will clean the best and to come up with a way to prove this. This assignment can be found in the CHiKhandbook. At the end of the lesson (2 hours) the student groups finished their experiments and reported on their findings. None of the students really succeeded in proving their hypothesis, but based on their experiences they are now able to formulate directions in which they should explore it further. The teacher wrote these suggestions on the blackboard and used them as the starting point for the next lesson. 
About this she remarked: 'I write down everything in the way the students bring it up. Even if I think it goes in a wrong direction. If I write it down from my own perspective, I will lose the students interest.' The students in each of her two classes came up with completely different experiments and suggestions, but the overall structure of the lessons in both her classes was similar, and as planned by the teacher. Summarizing, this teacher succeeded in implementing this stage as intended, explaining students' ideas and taking them seriously.

Teacher II introduced the context in the first lesson with the question: 'What do you taste in candy?' After tasting and studying candy according to the assignment the students concluded: 'You only taste aromas, not the colours'. In the next lesson the students were given an assignment on the chemical structure of aromas. This assignment was taken from another source than the CHiK-materials. The teacher employed different teaching activities to ensure that all students actively thought and talked about the subject, but the teacher decided what the students should do. The lesson was closed after finishing the nomenclature of the esters and summarizing a text on aromas. Hence, the context was only employed to introduce the subject 'aromas'. As the teachers says in the interview: 'The aim was to introduce a new theme, to have a motivated start. Because we have had an introduction about aromas and a little bit about esters before, I knew they would say; ooh aromas, that would have to do with esters, nice smell and so on. To get them from a point of I know something already and then to get them further.' Although students were actively involved in the lesson, they were not given the opportunity to formulate their own questions regarding the context. This teacher did not implement this episode as intended. 
Teacher III started by introducing the context, then giving the students time to think in groups about the problem, posed by the context, and presented on posters. To summarize, he made, together with his students, a mind map on the blackboard. This contained all kinds of suggestions to solve the problem; however, at the end of the lesson, he pointed at only one of the suggestions and stated without giving any argumentation, 'OK, we are going to focus on this idea in the next lesson.' He ignored all other ideas, not giving any feedback why these are not taken into account. Hence, this teacher did not take the students' ideas seriously. It can be concluded that he only succeeded partially in implementing this episode as intended.

Teacher IV introduced the context with an open discussion on the topic. Next she provided the students with background information and asked them to discuss the problem raised by the context in groups. Both the background information and the assignment can be found on the CD-ROM. At the end of the lesson she asked each group to summarize their discussions and to give suggestions on how to diminish the carbon dioxide concentration in the atmosphere. The lesson closed with a discussion in which she had to wait for the opportunity to introduce the question she needed for the next lesson. Because the students did not give the answer she wanted, she finally answered the question herself, directing her answer towards aspects that will be studied in the next lesson. 'The students focused on other aspects like fossil fuels. Therefore, I had to guide them towards the solubility of carbon dioxide in the oceans.' The teacher mentioned in the interview after the lesson that it required a lot of effort to steer the discussion in the desired direction. Hence, this teacher also only succeeded partially in implementing this episode as intended, not realizing an 'open' setting in which students follow their own curiosity. 
To summarize, only teacher I managed to implement this episode as intended, resulting in students' questions/ideas applicable for the planning of the following lessons. The other teachers did not implement this episode as intended. These three teachers actually skipped the entire critical episode by not explicating students' ideas. They employed the context as a means to go into the subject matter (teacher II), or as a topic/theme for a general discussion about which they had already decided in which direction it would go, neglecting most of the students' input (teachers III and IV).

\section{Implementation of critical episode 2}

Teacher I planned lessons in which students would be working towards a proof for the effect of acidic cleaners, as she explained in the interview: 'In the next lesson, the phase of contact will be finished by having the students to make recommendations on an acidic cleaner to use. I do not know what advice they will give, but the next assignment is to give proof for their advice.' The students formulated their expectations and questions which were intended to be answered within the focal event during the following lessons. But during the lessons of phase 3 the students were no longer aware of their formulated ideas. The teacher had to deal with big time-gaps between two subsequent lessons. As a result she had to repeat what they were working on and the student did not show much engagement or self-responsibility. After these lessons the teacher repeatedly mentioned: 'I had to tell the students what they had to do. They should bring in ideas themselves, but because the previous lesson was two weeks ago, they did not know anymore where they were working on. I disliked this lesson.' Hence, this teacher did not fully succeed in implementing this episode as intended by the designers and herself. However, this is not related to a factor in the teacher-material interaction. 
Teacher II let the students work in small groups, giving each group slightly different assignments. But the assignments were fully subject-matter oriented, instigated by the teacher and mostly selected from other sources than the CHiKmaterials. Student activities were fully controlled by the teacher, telling them exactly what and when to do. For example, she was able to follow exactly the same time planning for a lesson in two parallel classes. She remarked: 'ah nice, my planning works out so perfectly'. The teacher is aware of 'It is sometimes difficult for me to let the students go free without controlling them, but I am getting better at it. But in group work I always think, are they talking about the topic or about private things?' At the end of the lessons she employed activities to let the students communicate their results. When communicating about the assignments no references were made to the context and the students communicated mostly with the teacher instead of to the other students. To summarize, this teacher did not employ student-controlled learning activities, and thus implementation of this episode was not as intended.

Teacher III tried to implement group activities suggested in the teachers' guide, which are intended to stimulate communication and debate among the students. The following lessons were still focused on debate, but activities were more teachercontrolled to 'speed up the lessons, otherwise we need another two extra hours.' as the teacher remarked afterwards. He gave the students some time to discuss an assignment, followed by a full class discussion instigated and controlled by questions from the teacher. Most questions were oriented at subject-matter. He and his students were obviously not used to these activities, which resulted in much more time needed than expected by the teacher. Hence, this teacher only succeeded to a (very) limited extent in implementing this episode as intended. 
Teacher IV kept tightly to the assignment on the CD-ROM. The student groups were working on the same assignments at the same time in the same way, and this for four lessons in a row. At the end of the lessons the results were compared and discussed. Observations show that each group gave more or less the same results and arguments. Although the student groups were working independently, they were not working on their own questions. The lessons were teacher-controlled so that she could ensure that each student had learned all aspects dealt with in the assignments. This did not happen through students sharing their outcomes, but by each student doing every assignment. This took much more time than intended, and productive debates did not happen. Thus, this teacher also only succeeded to a limited extent in implementing this episode as intended.

To summarize, none of the teachers was able to fully implement this episode as intended. All four teachers did not succeed or did not even attempt to keep the focus on the students' own questions, giving them control over their learning activities.

\section{Perceived curriculum}

In this section the results on the third research question are presented: Which factors regarding teachers and material hinder or facilitate the implementation of such material as intended? In particular this question is regarded from the perspective of the two hypotheses formulated in the theoretical perspective: Do inadequate instructions and/or value incongruence hinder implementation as intended of the teaching materials? Data from the final interview and the emphasis questionnaire are the main input for the analysis.

Hypothesis 1: the need for concrete and direct instructions for the teacher. 
Analysis of the intended curriculum indicated that instructions on ground level are limited. The teachers' guide contains suggestions for activities to use in classroom practice, but it is up to the teacher to make the planning and to decide if and when these activities will be used. Instructions to the teachers are focused on the design model, explaining its aims and the teaching strategy on descriptive and theoretical levels. Instructions on how to apply the context during teaching are implicitly part of the design model. It is only suggested that students' questions evoked by the context should be the theme of the lessons, serving as focal events for student-controlled activities during the lessons.

As a co-designer of several units, teacher I is well aware of the design model and its meaning. She knows that in order to achieve the aims and strategy as intended, the teaching activities should be student-controlled. She consciously plans her lessons in such a way that there is time for improvisation, based on the input of the students. Open assignments are given in which students have to study their own questions. During lessons, the teacher is able to explain to the observer exactly why she planned the activities that take place in the classroom in terms of theoretical and descriptive goals (aims and strategy), referring to the aims and function of the different phases of CHiK. She does not need concrete ground-level instructions to plan her lessons.

In pre-service education, teacher III had received explanations concerning the CHiK design model. During the interview it appeared that he is conscious of the intended aims and teaching-learning strategy. As suggested in the teachers' guide, he attempted to apply student-oriented teaching activities, using the group-work assignments and initiating discussions between students about the context. Although he is aware that these activities are new to him, he was surprised by the amount of time they demanded and the difficulties in steering them in the desired direction. 
'That was the idea for today, group work on open questions via the jigsaw procedure, but we have to speed up a little.' This is one of the reasons that he took over control repeatedly, to speed up the lessons. This teacher showed that he does not yet have the necessary skills available to implement the intended teaching activities.

Teacher IV did not receive any instructions besides those in the teachers' guide. In classroom practice, she applied the assignments on the CD-ROM exactly as they were given. The instructions are not sufficient to let it happen as intended. She has a lack of knowledge about the intentions on descriptive and theoretical levels. She was unable to answer questions about the meaning and implications of the four phases of $\mathrm{CHiK}$ and did not even seem to know about their existence. Concrete instructions are not available although teachers have to plan their own lessons. The assignments were applied, but all of the student groups worked on exactly the same assignments. As a result there was no need to communicate and discuss. The teacher stimulated discussions about the context in each lesson, but these were mostly plenary teachercontrolled conversations. Theoretical and descriptive goals were only slightly achieved.

Teacher II used many different assignments to engage the students actively in her lessons. But these assignments were based on other sources than the CHiK-handbook, with the consequence that these did not have a direct relation to the context. Hence, this case does not tell much about the first hypothesis.

These results indicate that teachers need to have knowledge about the intentions on theoretical and descriptive levels and the skills to be able to construct a setting in which ground level activities can take place as intended. Lessons cannot be built on the limited amount of ground-level instructions in these materials alone. These are not enough to facilitate implementation as intended, effective instructions on descriptive 
and theoretical level are required too. This confirms the first hypothesis that if teachers are not supported adequately in the implementation of concrete teaching activities, that implementation of the materials as intended by the designers will not take place.

\section{Hypothesis 2: the need for value congruence}

We did establish that teachers require knowledge on theoretical and descriptive levels to be able to implement the $\mathrm{CHiK}$ teaching materials as intended. This implies that 'value congruence' might be a crucial factor for implementation as intended. The way the teachers perceive the materials might, to a large extent, determine if the designers' intentions with the materials will be implemented.

As mentioned before, teacher $\mathrm{I}$ is well aware of the intentions of the materials. By explaining what she is doing she expresses that she highly values the materials. She uses argumentations for the decisions she makes that is coherent with the intentions with the materials (e.g. see previous arguments). Her answers on the questionnaire (Markic et al., 2009) show that for propositions on learning outcomes she values each emphasis almost equally. But she has a high preference for approaching chemical content from a societal or technological perspective. This is coherent with the way she applies the context, as a thematic introduction of issues in which chemistry plays a role, closely related to the daily life of students. This orientation on students in her teaching is also shown in the questionnaire in which she values highest the aspects related to a student-oriented approach. To conclude, teacher I shows value congruence and her implementation does not show any incoherencies that can be related to this aspect. This case supports our hypothesis that value congruence facilitates implementation as intended. 
Although teacher II is, in general, positive regarding the teaching materials of $\mathrm{CHiK}$, value incongruence is found on an important feature of $\mathrm{CHiK}$ : the employment of context. In general, hardly any clues are found indicating value incongruence. Her answers on the questionnaire do not show a significant preference for a particular emphasis, nor regarding the aim for teaching nor the way it should be employed. The questionnaire is clear about her preference for a student-oriented approach although she also values subject-oriented aspects. This does not indicate incoherence to the intended curriculum. The interviews reveal that she recognizes the large variety of student-oriented activities as the main characteristic of $\mathrm{CHiK}$. 'I think I reached the students better by these lessons, then in the years before.' But the interviews also show that she is not aware of the function that the context has in the teaching-learning strategy and that she does not value the way the context is employed. As she remarked in the final interview: 'the students got motivated by the context, but it is only entertaining. The students were more motivated in comparison to other lessons. I used the context in the beginning, at the end I referred back to it, but in between it was in the background. I think they liked the start and in the last lesson they were asking: can we eat gummy bears again.'. The context was actually only employed in the first lesson to introduce the topic. Based on this seemingly limited understanding of the materials she employed assignments that were not coherent with the intentions, leaving out the context and mainly aiming at subject matter/FC emphasis.

Teacher III does not explicitly express his opinion concerning $\mathrm{CHiK}$ or the materials when asked for this in the interviews. The questionnaire does not reveal large discrepancies between his view on teaching and the intentions of the designers, although they do not coincide fully. He seems to be mostly oriented to the FCemphases and to value subject-oriented aspects highest. This belief structure, 
combining the FC-emphasis with subject matter orientation, is incongruent with the intentions of the materials. On questions in the interviews about the aims he only refers to subject matter knowledge: 'Next lesson is about chemical equilibrium and reaction rates. And after that about what effects equilibrium, such as temperature. I like to spend one hour on the Haber-Bosch process and very short about ammonia and the chemical process for nitric acid.' This was visible in the realized classroom practice in which the four phases of $\mathrm{CHiK}$ are followed, but in which the teacher took over control to focus more rapidly on the subject-matter related aspects. Hence, this case also supports our hypothesis: value incongruence hinders implementation as intended.

Teacher IV mainly followed the ground-level instructions, implying that value (in)congruence plays a minor role in her decisions regarding how the materials are implemented. She does not seem to have objections concerning the use of the context or the aims in the materials, showing a positive attitude. 'It was very interesting, because there is a lot of material which concerns themes that are very important for our future.' She repeatedly mentioned in the interview that she really liked the assignments and discussions around the context. She hardly used debate on descriptive or theoretical levels to express her opinion about the materials. The questionnaire indicates 'value congruence'. Her general values concerning teaching chemistry do coincide with those of CHiK. She values highest the CTS-emphasis, but does not reject the other emphases. This emphasis orientation is combined with a student-oriented view on teaching. In this case value congruence might have been helpful to achieve coherent implementation, hence it provided a weak support for our hypothesis. 
To summarize, value congruence seems to support teachers I and IV in implementing a classroom practice as intended by the designers. Teacher III also confirms our hypothesis: value incongruence hinders implementation as intended. Teacher II shows a lack of understanding on a major aspect, namely viewing the employment of contexts in classroom only as entertainment. This value incongruent interpretation hindered implementation as intended severely.

\section{Overview of the four cases}

In Figure 4 the implementation by the four teachers is illustratively summarized. The light-grey colour indicates the situation that the cells of the perceived and operational curriculum are coherent to the cells of the intended curriculum. The medium-grey colour indicates that this is partially the case and the dark-grey colour indicates that there is no coherence with the intended curriculum.

\section{[Insert Figure 4 about here]}

\section{Conclusions}

This paper focuses on the implementation of 'Chemie im Kontext' intentions and teaching-materials. The aim is to study factors that hinder or facilitate implementation as intended by the designers of these context-based materials. We used a case study approach (Creswell, 2007) with four experienced teachers, who have different degrees of experiences with $\mathrm{CHiK}$, and the analytical framework described by Authors (in press). This resulted in the following conclusions.

The first research question was: To what extent have the 'Chemie im Kontext' teaching materials a coherent design? 
It is concluded that the design of the materials is coherent, although complex, which might hinder adequate communication to the teachers. Analysis revealed that two episodes in the teaching materials are critical for implementation according to the rationale of the $\mathrm{CHiK}$-approach. Activities central in these episodes: 1. Eliciting students' questions by the context and 2. Maintaining student-controlled learning activities (focused on their own questions).

The second research question was: To what extent are 'Chemie im Kontext' teaching materials implemented adequately by German teachers with different degrees of experiences with context-based education?

Implementation is illustrated by the two critical episodes, which are representative for critical teaching activities according to the intentions of $\mathrm{CHiK}$.

One teacher (Teacher I, the most experienced in $\mathrm{CHiK}$ ) realized a setting in classroom practice in which students were able to formulate researchable questions regarding the context. These questions were employed as the focal event to plan the following lessons. Mainly due to big time-gaps between these lessons the students did not show engagement with the context and their own questions. This resulted in teacher-controlled activities instead of student-controlled activities as was intended by the designers (and the teacher).

The other three teachers did not put the intended focus on the formulation of students' questions and they did not employ these questions as the focal event for the planning of the following lessons. Regarding the four-phase cycle of $\mathrm{CHiK}$, they actually skipped nearly the entire second phase. In the first phase general students' ideas and questions are evoked, but these are not developed as intended. Therefore, they cannot serve as the source for planning the following lessons. Teacher II employed assignments to actively involve the students, but without referring to the 
context. Activities to let control students their own activities (based on their need to expand knowledge) are not observed in this case. Teachers III and IV kept the context central, and engaged the students by starting open discussions about it. But students' questions were not made explicit and during the following lessons these were out of focus. The teachers decided on which assignments the students had to work on without relating these assignments to the students' questions. On the ground-level the activities were more initiated by the teacher instead of controlled by the students.

Hence, the conclusion is that none of the teachers was able to implement these episodes fully as intended by the designers (see also Figure 4), although one of the teachers implemented it to a large extent as intended.

The third research question was: Which factors regarding teachers and material hinder or facilitate the implementation of such materials as intended?

Two hypotheses were formulated. The first hypothesis is confirmed that if concrete and direct instructions are not adequately supporting teachers in the implementation of concrete teaching activities, implementation as intended will not take place, unless the teacher has a deep understanding of the intentions with the materials.

Analysis revealed that ground-level instructions are limited available in the teaching materials. The materials contain suggestions for assignments and organizing different teaching strategies like group work, but the teachers have to plan the lessons themselves. Teachers can ignore these suggestions fully as was done by teacher II. As expected, teachers with little or no experiences with CHiK rely mostly on groundlevel instructions. Teacher III started group-work activities, but as soon as these took too long and deviated from the desired subject matter he transformed these activities into teacher-controlled instruction. He was not highly skilled in this repertoire of new 
teaching activities, yet. Thus in this case a lack of (ground-level) skills was a hindering factor for implementation as intended. Teacher IV applied the assignments as written in the material, but there was no setting observed in her lessons that framed the students' activities. Besides, there was no need for the students to communicate about the subject among themselves, as intended. It can be concluded that for the realization of a classroom practice representing all intentions of $\mathrm{CHiK}$ on all levels, ground-level instructions alone are not enough. Ground-level activities are not automatically embedded in a setting provided by the context.

Teacher I did not use ground-level instructions explicitly, but based on theoretical and descriptive argumentation she was able to create a setting in which students' activities took place in coherence with the theoretical and descriptive intentions. Therefore, we conclude that teachers require understanding of the theoretical aims and the teaching-learning strategy to be able to establish a setting in their classrooms in which learning activities can take place as intended. In terms of Gilbert (2006), the behavioural environment may be of a higher quality, dependent on the teacher's understanding of the setting being used. In the situation of $\mathrm{CHiK}$, the context employed in the phase of contact (1) is too general to be effectively applicable as a setting in which activities, such as the students' developing their own ideas and beginning to explore these logically, take place. This give rise to critical episode 1 , which proved to be difficult to implement as intended.

The second hypothesis focused on the need of value congruence between the teachers' perceptions of the materials and the designers' intentions. We conclude that value congruence is necessary for an adequate implementation of CHiK-materials as intended. 
In the case of teacher II value incongruence was observed concerning a major aspect of $\mathrm{CHiK}$, the employment of contexts. This caused her to ignore the groundlevel instructions and introduce her own assignments fitting to her own emphasis orientation and perceived teaching-learning strategy. In this case we conclude that value incongruence hinders the implementation as the designers intended.

Although teachers III and IV's classroom practices are mostly based on groundlevel instructions, their values concerning chemistry education are influential on how the teaching materials are implemented. Teacher III values highest the FC-emphasis combined with a subject matter orientation. This indicates value incongruence with the materials. Student-controlled group work took more time than he expected and it was difficult for this teacher to keep the focus on what he perceived as important. This stimulated this teacher to take over control and to direct the students' activities towards the desired chemistry content. We conclude that even though this teacher intended to follow the instructions in the materials, value incongruence in combination with a little amount of experiences with $\mathrm{CHiK}$ hindered adequate implementation. In contrast, teacher IV's values concerning chemistry education indicate value congruence. Although the lessons took more time than expected, she was willing to spend this extra time and to complete the lessons as she thought was intended. Although this teacher has a lack of knowledge concerning the intentions on descriptive and theoretical knowledge, value congruence is visible and this helps facilitating implementation as intended.

Teacher I did show value congruence. Her understanding of and agreement with the materials' intentions allowed her to realize a classroom setting in which the questions of students are made explicit. She is aware of the crucial role of it in the teaching-learning strategy of $\mathrm{CHiK}$. That further implementation was not fully as 
intended can be explained by an external factor, big time-gaps between lessons. This is not related to the interaction between teacher and teaching material.

To summarize, value congruence is a necessary factor for an adequate implementation of CHiK-materials as intended. Obviously, concrete and direct instructions in the materials are a facilitating factor, but on themselves they are not enough to facilitate implementation. Teachers are also required to have knowledge about the rationale of $\mathrm{CHiK}$, to value all aspects of it, and should have the skills to apply the materials adequately in the classroom.

\section{Discussion and Implications}

Based on these conclusions the following recommendations can be made.

First, extensive teacher professionalization is required to provide teachers with an opportunity to develop a full understanding of the rationale of the approach. This is of particular importance because the $\mathrm{CHiK}$ approach represents a complex design integrating multiple educational aims (for instance different competencies) and views on learning and motivation of students.

As extensive teacher professionalization is not always possible, new materials to be developed should make use of a detailed design of concrete teaching activities in such a way that teachers intuitively feel what should be done. This requires that theoretical and descriptive aims are adequately translated into teaching activities which will follow logically from the context. The context should be chosen carefully in such a way that they match the intended learning goals and that they provide a specific setting (via a focal event) for the intended activities of teacher and students. 
Finally, crucial aspects should be communicated to the teachers explicitly, and in such a way that they know which aspects they have to realize in order to implement $\mathrm{CHiK}$ and which aspects they can adapt to the needs of their specific situation.

The conclusions in this paper are based on a limited number of cases, four teachers with varying experiences in teaching with $\mathrm{CHiK}$-materials. Each teacher represents one case, each with its own specific characteristics. Although detailed descriptions of these cases are available indicating factors as value (in)congruence, high/low-skilled in required teaching activities, and high/low understanding of rationale and strategy, further research is required for generalization of the conclusions. Conclusions regarding these factors and the relation to (in)adequate implementation will be more valid if confirmed by more cases which are characterized by the same factors.

\section{References}

\section{Authors (submitted). Journal of Research in Science Teaching}

Authors (in press). Teachers implementing context-based teaching materials: A framework for case-analysis in Chemistry. Chemistry Education, Research and Practice

Abd-El-Kahlick, F., Lederman, N.G. (2000). Improving science teachers' conceptions of nature of science: a critical review of the literature. International Journal of Science Education, 22, 665-701

Bennett, J., Lubben, F., \& Hogarth, S. (2007). Bringing science to life: A synthesis of the research evidence on the effects of context-based and STS approaches to science teaching, Science Education, 91, 347-370.

Borko, J. (2004). Professional development and teacher learning: Mapping the terrain. Educational Researcher, 33(8), 3-15. 
Bulte, A.M.W., Westbroek, H.B., De Jong, O., \& Pilot, A. (2006), A research approach to designing chemistry education using authentic practices as contexts. International Journal of Science Education, 28(9), 1063-1086.

Coenders, F., Terlouw, C., \& Dijkstra, S. (2008). Assessing Teachers' Beliefs to Facilitate the Transition to a New Chemistry Curriculum: What Do the Teachers Want? Journal of Science Teacher Education, 19, 317-335.

Creswell, J.W. (2007). Qualitative Inquiry \& Research Design: choosing among five approaches. Thousand Oaks, CA: Sage Publications.

Cronin-Jones, L. (1991). Science teacher beliefs and their influence on curriculum implementation: Two cases studies. Journal of Research in Science Teaching, 28, $235-250$.

Davis, E.A., \& Krajcik, J.S. (2005). Designing educative curriculum materials to promote teacher learning. Educational Researcher, 34(3), 3-14.

Deketelaere, A. \& Kelchtermans, G. (1996). Collaborative curriculum development: an encounter of different professional knowledge systems. Teachers and teaching: theory and practice, 2, 71-85.

Demuth, R., Gräsel, C., Parchmann, I., \& Ralle, B. (2008). Chemie im Kontext; Von der Innovation zur nachhaltigen Verbreitung eines Unterrichtskonzepts. ['Chemie im Kontext'; from innovation to subsequent spreading of a educational concept] Münster: Waxmann Verlag.

Demuth, R., Parchmann, I., \& Ralle, B. (Eds.). (2006). Chemie im Kontext Sekundarstufe II. Berlin: Cornelsen.

Demuth, R., Parchmann, I., \& Ralle, B. (Eds.). (2007). Handreichungen fur den Unterricht. Chemie im Kontext - Sekundarstufe II. Berlin: Cornelsen. 
Driessen, H.P.W. \& Meinema, H.A. (2003). Chemistry between concepts and context, designing for renewal. Enschede, SLO, Stichting Leerplanontwikkeling. (www.nieuwescheikunde.n1/00004/00001/)

Gilbert, J.K. (2006). On the nature of 'context' in chemical education. International Journal of Science Education, 28(9), 957-976

Goodlad, J. (1979). Curriculum inquiry: the study of educational practice. New York, NY: McGraw-Hill.

Harland, J. \& Kinder, K. (1997). Teachers' continuing professional development: framing a model of outcomes. British Journal of In-service Education, 23(1), 7184

Johnston, S. (1992). Images: A way of understanding the practical knowledge of student teachers. Teacher and Teacher Education, 8, 123-136

Korthagen, F.A.J., \& Kessels, J.P.A.M. (1999). Lining theory and practice: Changing the pedagogy of teacher education. Educational Researcher, 28(4), 4-17.

Lederman, N.G. (2007). Nature of science: past, present, and future. In S. K. Abell \& N. G. Lederman (Eds.), Handbook of research on science education (pp. 831-879): Lawrence Erlbaum Associates.

Mandl, H. \& Kopp, B. (2005). Situated Learning: theories and models. In P. Nentwig \& D. Waddington (Eds.), Context based learning of Science; Making it relevant (pp. 15-34). Munster, Germany: Waxmann.

Markic, S., Eilks, I., Van Driel, J., \& Ralle, B. (2009). Vorstellungen deutscher Chemielehrkräfte über die Bedeutung und Ausrichtung des Chemielernen. [The conceptions of German Chemistry Teachers about teaching and learning chemistry], ChemKon, 16, 90-94 
McKenney, S., Nieveen, N., \& Van den Akker, J. (2006). Design research from a curriculum perspective. In J. Van den Akker, K. Gravemeijer, S. McKenney, \& N. Nieveen (Eds.), Educational Design Research (pp. 110-143). London, UK: Routledge.

Nentwig, P., Parchmann, I., Demuth, R., Gräsel, C., \& Ralle, B. (2005). Chemie im Kontext - From situated learning in relevant contexts to a systematic development of basic chemical concepts. In P. Nentwig \& D. Waddington (Eds.), Context based learning of Science; Making it relevant (pp. 121-153). Munster, Germany: Waxmann.

Nentwig, P. \& Waddington, D. (Eds.). (2005). Context-based learning of Science; Making it relevant. Munster, Germany: Waxmann.

Parchmann, I., Gräsel, C., Baer, A., Nentwig, P., Demuth, R., Ralle, B., \& the CHiK Project Group. (2006). 'Chemie im Kontext': A symbiotic implementation of a context-based teaching and learning approach. International Journal of Science Education, 28, 1041-1062

Pilot, A. \& Bulte, A.M.W. (2006). The use of 'Contexts' as a challenge for the chemistry curriculum: Its successes and the need for further development and understanding. International Journal of Science Education, 28, 1087-1112

Roberts, D.A. (1982). Developing the concept of 'curriculum emphasis' in science education. Science Education, 66(2), 243-260

Roberts, D.A. (1988). What counts as science education? In P.J. Fensham (Ed.), Development and dilemmas in science education (pp. 27-54). London, UK: Routledge Falmer. 
1

2

3

4

5

6

7

8

9

Van den Akker, J.J.H. (1994). Designing innovations from an implementation perspective. In T. Husén and T.N. Postlethwaite (Eds.), The International Encyclopaedia of Education (pp. 1491-1494). Oxford, UK: Pergamon Press.

Van Driel, J.H., Bulte, A.M.W., \& Verloop, N. (2005). The conceptions of chemistry teachers about teaching and learning in the context of a curriculum innovation. International Journal of Science Education, 27(3), 303-322

Van Hiele, P.M. (1986). Structure and insight: a theory of mathematics education. New York, NY: Academic Press. 
Figure 1: The analytical framework represented as a matrix. 


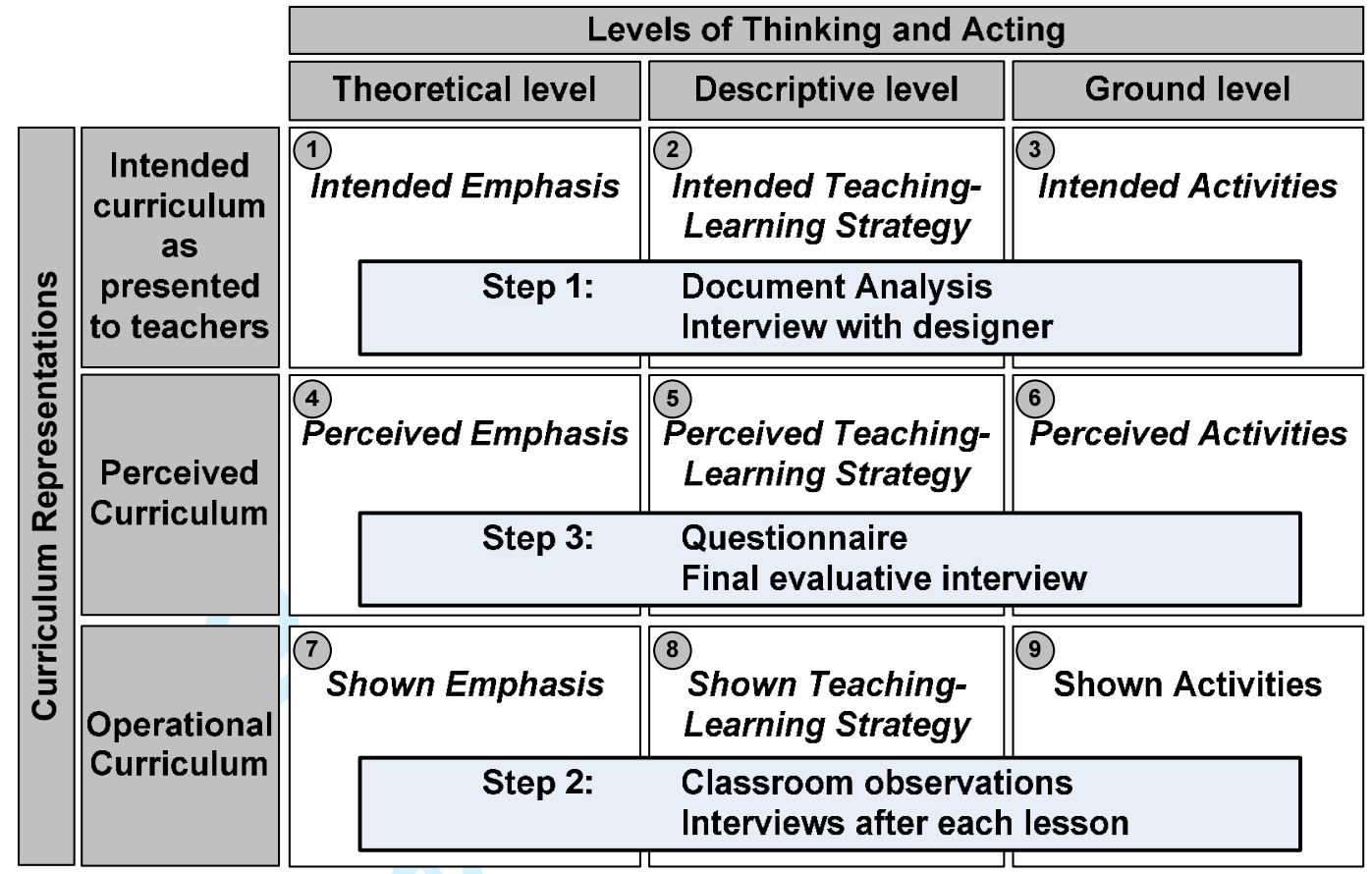

Figure 2: Framework for analysis, indicating the focus of the steps of analysis. 


\section{Phase of Deepening and Connecting}

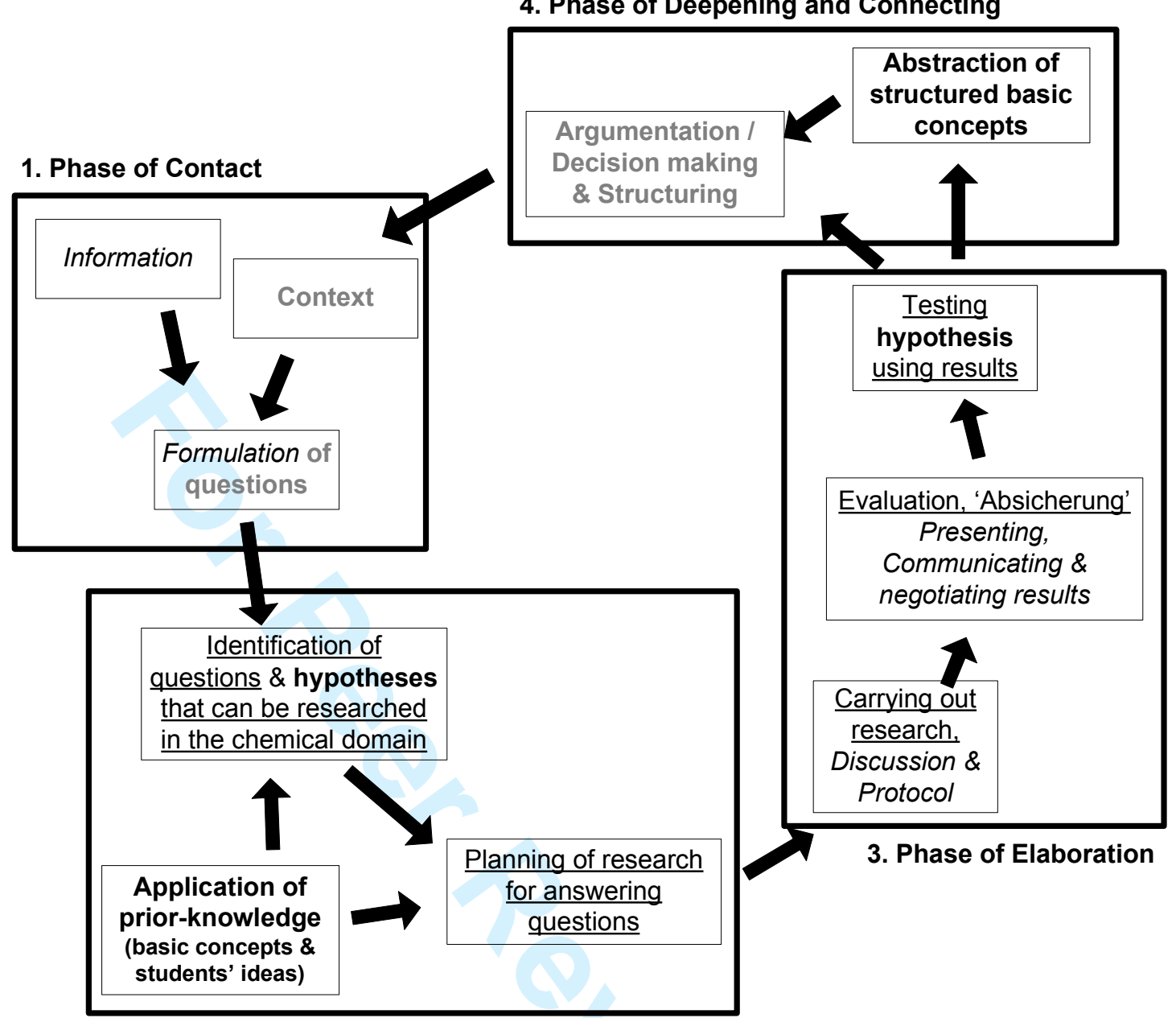

2. Phase of Curiosity and Planning

Figure 3: Design model underlying design of ChiK-materials. In Bold: competency "subject matter knowledge", in Italic: competency "Communication", Underlined: competency "Scientific Methodologies" and in Grey: competency "Debate/Reasoning". Translated from the teachers' guide (Demuth et al., 2007, p. 9) 
Figure 4: Findings on coherence, representing the implementation by the four teachers. Light-grey=as intended (coherent with upper row). Medium-grey = partly as intended. Dark-grey = not as intended (no coherence with upper row). 